\title{
Two Paths of Sequence Divergence in the Citrus Tristeza Virus Complex
}

\author{
Mark E. Hilf, Alexander V. Karasev, Maria R. Albiach-Marti, William O. Dawson, and Stephen M. Garnsey
}

First and fifth authors: USDA-ARS, Horticultural Research Laboratory, 2120 Camden Road, Orlando, FL 32803; and second, third, and fourth authors: University of Florida, Department of Plant Pathology, Citrus Research and Education Center, Lake Alfred 33850. Accepted for publication 8 January 1999.

\begin{abstract}
Hilf, M. E., Karasev, A. V., Albiach-Marti, M. R., Dawson, W. O., and Garnsey, S. M. 1999. Two paths of sequence divergence in the citrus tristeza virus complex. Phytopathology 89:336-342.

Comparison of a sampling of complementary DNA (cDNA) sequences from the Florida citrus tristeza virus (CTV) isolates T3 and T30 to the sequence of the genome of the Israeli isolate VT showed a relatively consistent or symmetrical distribution of nucleotide sequence identity in both the $5^{\prime}$ and $3^{\prime}$ regions of the 19.2-kb genome. In contrast, comparison of these sequences to the sequence of isolate T36 showed a dramatic decrease in sequence identity in the $5^{\prime}$ proximal $11 \mathrm{~kb}$ of the genome. A cDNA probe derived from this region of the T36 genome hybridized to double-stranded RNA (dsRNA) of only 3 of 10 different Florida CTV isolates. In contrast, analogous probes from T3 and T30 hybridized differentially to the seven isolates not selected by the T36 probe. Primers designed from cDNA se-

quence for polymerase chain reaction (PCR) selectively amplified these 10 isolates, allowing them to be classified as similar to T3, T30, or T36. In contrast, individual cDNA probes derived from the $3^{\prime}$ terminal open reading frames of the T3, T30, and T36 genomes all hybridized to dsRNA from all Florida CTV isolates tested, and PCR primers designed from the T36 capsid protein gene sequence amplified successfully from all isolates. Based on these data, we propose the creation of two groups of CTV, exemplified by the VT and T36 isolates, respectively. Isolates in the VT group, which include isolates VT, T3, and T30, have genomic sequence divergence that is relatively constant in proportion and distribution throughout the genome, and candidate isolates for that group could be considered strains of the same virus. The T36 group is differentiated from the VT group by the highly divergent $5^{\prime}$ genomic sequence. This $5^{\prime}$ region of the CTV genome, thus, can serve as a measure of the extent of sequence divergence and can be used to define new groups and group members in the CTV complex.
\end{abstract}

Citrus tristeza virus (CTV) is a member of the closterovirus group of (+)-sense, single-stranded RNA plant viruses. CTV is a phloemassociated virus with a host range primarily in the genus Citrus. Aphids spread the virus naturally, but infections are also perpetuated in commercial citrus plantings through vegetative propagation. Trees are commonly exposed to multiple aphid-borne inoculations during a life that is expected to be several decades. Isolates of CTV differ greatly in the symptoms they induce in citrus (6). Some isolates cause a graft incompatibility between scion and sour orange rootstocks, called decline or quick decline, that often results in tree death. Other isolates cause severe stem pitting that affects tree growth and productivity, but does not lead to tree death. Some isolates are essentially benign in most citrus hosts. There is evidence that CTV isolates frequently are populations from which variants with distinct properties can be selected $(2,9,20)$ and that also often contain multiple defective RNAs (DRNAs) $(15,17)$. A disease phenotype may, therefore, result from a mixture of viral components that exist in different proportions and coreplicate in infected plants.

The Florida CTV isolate T36 was isolated from an aphid-inoculated tree in a grove undergoing an epidemic of quick decline disease (7). The sequence of the capsid protein gene of T36 was determined by Sekiya et al. (24), and subsequent analyses of the sequences of the capsid protein genes of symptomatically and geographically different isolates of $\operatorname{CTV}(8,16,22)$ showed that the

Corresponding author: M. E. Hilf; E-mail address: Markhilf@aol.com

Mention of a trade name, proprietary product, or specific equipment does not constitute a guarantee or warranty by the U.S. Department of Agriculture and does not imply approval to the exclusion of other products that may also be suitable.

Publication no. P-1999-0223-01R

This article is in the public domain and not copyrightable. It may be freely reprinted with customary crediting of the source. The American Phytopathological Society, 1999. capsid protein gene was highly conserved. From these data, it was inferred that there were only minor genetic differences between isolates characterized by distinct biological differences.

The complete genomic sequence of T36 was determined by Karasev et al. (11), and recently, the complete sequence of VT, a decline-inducing isolate from Israel, was determined by Mawassi et al. (18). Comparison of the sequences of VT and T36 indicated that the nucleotide sequences of the two isolates were highly conserved throughout the $3^{\prime}$ terminal 8,400 nucleotides, but showed a gradual increase in sequence divergence toward the $5^{\prime}$ terminus, changing from $97 \%$ sequence identity in the $3^{\prime}$ nontranslated region (NTR) to $47 \%$ sequence identity in the $5^{\prime}$ NTR. This difference in nucleotide sequence identity between T36 and VT in the $5^{\prime}$ region (30 to $40 \%$ ) was greater than expected, whereas the similarities in the $3^{\prime}$ regions were within normal expectations $(<10 \%$ sequence divergence) for strains of the same virus.

This observation raised several questions about different CTV populations. Do all CTV genomes differ in this asymmetrical manner, or does this genome asymmetry indicate the existence of subgroups of CTV isolates? Or, perhaps either VT or T36 is atypical, with either T36 or VT being a chimera between a typical CTV sequence and a significantly different closterovirus. Could these two CTV genotypes be evolved from an ancestral CTV genotype that has undergone unequal or asymmetric rates of divergence within the progeny genomes?

To determine whether the sequences of other isolates could be definitively grouped with either T36 or VT, we examined representative Florida isolates with different biological characteristics and, hence, potentially diverse genotypes. The specific objective of this analysis was to determine if and how VT and T36 may be representative of the genetic diversity of Florida CTV isolates. To that end, we cloned representative complementary DNA (cDNA) sequences from the $5^{\prime}$ and $3^{\prime}$ regions of two Florida CTV genomes and analyzed their source RNA populations by Northern blot hybridization. 


\section{MATERIALS AND METHODS}

Virus maintenance. The Florida CTV isolates T3, T4, T30, T30-1, T36, T49-1, T55-1, T56-1, T64-1, T66-1, and T68 were maintained as part of a collection in a greenhouse and were propagated in 'Madam Vinous' sweet orange (Citrus sinensis (L.) Osbeck), 'Etrog' citron (C. medica L.), or Mexican lime (C. aurantifolia (L.) Swingle). The general characteristics of these isolates are listed in Table 1 . The isolate T36 and all isolate numbers with the suffix (-1) are aphid-transmitted subisolates from the original source plants. These isolates were characterized and grouped based upon symptoms induced after infection of specific indicator hosts (6). The isolate T3 was isolated from a lime tree (9). Isolate T36 was obtained from a sweet orange tree (7), whereas T64-1 and T66-1 were isolated from grapefruit trees on sour orange rootstocks undergoing CTV-induced decline. Isolate T68 was obtained from an 'Ellendale' mandarin tree (C. reticulata) propagated from budwood imported from Australia without authorization. Isolate T4 was obtained from a naturally infected 'Etrog' citron tree, while T30 and T30-1 originated from Mexican lime indicator plants. Isolates T49-1 and T55-1 originated from commercial 'Navel' and 'Valencia' sweet orange cultivars propagated on sour orange rootstock that harbored symptomless infections of CTV for many years. Isolate T56-1 originated from a 'Valencia' tree at a citrus budwood nursery run by the Division of Plant Industry in Dundee, FL (26).

Double-stranded RNA (dsRNA) isolation and gel blot analysis. CTV-specific dsRNA was purified from infected citrus tissue as described $(21,25)$, and Northern blot hybridizations using purified dsRNA were performed as described (10).

cDNA synthesis, molecular cloning, and sequencing. Total dsRNA or polyacrylamide gel-purified genome-sized dsRNA was denatured either by heating at $100^{\circ} \mathrm{C}$ for $3 \mathrm{~min}$ followed by snapcooling in an ice slurry or with methyl mercuric hydroxide (14).

First-strand cDNA was synthesized from denatured total dsRNA using random hexamers (Boehringer Mannheim Biochemicals, Indianapolis, IN) as primers and Moloney murine leukemia virus reverse transcriptase (MMLV-RT) (Promega Corp., Madison, WI) according to supplier's recommendations. Second-strand cDNA synthesis, restriction endonuclease digestion and ligation into appropriately digested pBluescript $\mathrm{SK}(+)$ vector (Stratagene Inc., La Jolla, CA), and transformation were done using standard protocols (14). Also, gel-purified genome-sized dsRNA was modified by polyadenylation (1), and cDNA was synthesized from this template using avian myeloblastosis virus reverse transcriptase and the primer M111 (12), which contained a XhoI restriction endonuclease site and an oligo-dT $\mathrm{T}_{18}$ portion. cDNA was amplified by polymerase chain reaction (PCR) using the M111 primer (12), and then gel-purified from $1 \%$ agarose, digested with XhoI, and cloned into XhoI-digested pGEMz cloning vector (Promega Corp.) using standard procedures.

The clone T308 was synthesized from randomly primed cDNA prepared from dsRNA of the Florida isolate T30. The cDNA was used as the template for amplification by PCR using the profile of 30 cycles of $60 \mathrm{~s}$ at $94^{\circ} \mathrm{C}, 60 \mathrm{~s}$ at $40^{\circ} \mathrm{C}$, and $90 \mathrm{~s}$ at $72^{\circ} \mathrm{C}$. The forward and reverse primers, $5^{\prime}$ GTTATCACGCCTAAAGTTTGGT3' and 5'CATGACATCGAAGATAGCCGAA3', respectively, were synthesized from sequence derived from the cDNA clone T3MT.

The cDNA clone T3041 was generated by PCR from randomly primed cDNA synthesized on the T30-specific dsRNA template, using the (+)-sense degenerate primer D2134, derived from the sequence of the conserved motif IV of the CTV RNA-dependent RNA polymerase, and the specific (-)-strand primer D2146 (12,11).

Virion immunocapture and cDNA synthesis. Sap was expressed from citrus bark by pulverizing $0.3 \mathrm{~g}$ of fresh or $0.1 \mathrm{~g}$ of desiccated citrus bark tissue in $3 \mathrm{ml}$ of phosphate-buffered saline (PBS) (0.14 $\mathrm{M}$ sodium phosphate buffer, $\mathrm{pH} 7.4$, and $0.15 \mathrm{M}$ sodium chloride), and extracts were centrifuged at $12,000 \times g$ for $10 \mathrm{~min}$ at $4{ }^{\circ} \mathrm{C}$. Dynabeads M-280 (Dynal, Oslo, Norway), coated by the supplier with sheep anti-rabbit immunoglobulin $\mathrm{G}(\mathrm{IgG})$ at $10 \mu \mathrm{g}$ of IgG per mg of beads and supplied at $10 \mathrm{mg} / \mathrm{ml}$, were reacted with anti-CTV rabbit polyclonal antibodies at a ratio of $5 \mu \mathrm{g}$ of anti-CTV IgG per $1 \mu \mathrm{g}$ of sheep anti-rabbit IgG. Ten to twenty microliters of CTV-sensitized beads was added to $0.5 \mathrm{ml}$ of the above supernatant and incubated at ambient temperature for $2 \mathrm{~h}$. The beads were retrieved from solution on a magnetic stand and washed three times with $0.5 \mathrm{ml}$ of PBS, and beads with bound virus were stored in $\mathrm{PBS}$ at $4^{\circ} \mathrm{C}$ for up to 2 weeks prior to use.

First-strand cDNA was prepared from immunocaptured virions by adding $20 \mu \mathrm{l}$ of a mixture of $50 \mathrm{mM}$ Tris- $\mathrm{HCl}, \mathrm{pH} 8.3 ; 7 \mathrm{mM}$ $\mathrm{MgCl}_{2} ; 40 \mathrm{mM} \mathrm{KCl} ; 10 \mathrm{mM}$ dithiothreitol; $0.1 \mathrm{mg}$ of bovine serum albumin per ml; $500 \mu \mathrm{M}$ dNTPs; $0.0625 A_{260}$ units of random hexamers; 20 units of RNasin (Promega Corp.); and 200 units of MMLV-RT, followed by incubation at $37^{\circ} \mathrm{C}$ for $45 \mathrm{~min}$. The reaction was next heated at $65^{\circ} \mathrm{C}$ for $10 \mathrm{~min}$, after which $30 \mu \mathrm{l}$ of sterile, deionized water was added to each reaction. Reactions not used immediately were stored at $-20^{\circ} \mathrm{C}$.

PCR with sequence-specific CTV primers. Two to five microliters of cDNA was amplified in a $50-\mu 1$ reaction volume containing $0.2 \mathrm{mM}$ dNTPs, $1.5 \mathrm{mM} \mathrm{MgCl}_{2}, 0.2 \mu \mathrm{M}$ of each primer, and 1.25 units of Amplitaq DNA polymerase (Perkin Elmer, Branchburg, NJ) for 30 cycles of $30 \mathrm{~s}$ at $94^{\circ} \mathrm{C}, 60 \mathrm{~s}$ at $56^{\circ} \mathrm{C}$, and $60 \mathrm{~s}$ at $72^{\circ} \mathrm{C}$. PCR products were analyzed on $1.5 \%$ agarose gels containing $200 \mathrm{ng}$ of ethidium bromide per $\mathrm{ml}$.

DNA sequencing and analysis. Virus-specific clones were sequenced directly in dsDNA recombinant plasmids using the Sequenase 2.0 sequencing kit (United States Biochemical Corp., Cleveland), the forward and reverse universal, and $\mathrm{T} 3$ and $\mathrm{T} 7$ sequencing primers as described previously (11). The nucleotide sequences were compared with the genomic sequences of the CTV isolates T36 (GenBank accession no. U16304) and VT (EMBL accession no. U56902) using the MACAW program (23) and the UWGCG program (4).

\section{RESULTS}

Sampling of T30 sequences. Randomly primed cDNA clones prepared from T30-specific dsRNA were used as probes in Northern blot hybridizations to confirm that the cloned sequence represented the majority of sequences present in the source RNA population (data not shown).

Table 2 shows the genomic positions of the partial sequences of 18 clones that span the T30 genome, as concluded from the computer alignment of these sequences with the complete genomic sequences of the Florida isolate T36 and the Israeli isolate VT. For each clone, the size of the sequenced portion in nucleotides, its genomic position, and estimated percentage nucleotide sequence identity to the homologous region of the T36 and VT genomes are

TABLE 1. Characteristics of representative Florida citrus tristeza virus isolates

\begin{tabular}{llll}
\hline Isolate & Origin & Source $^{\mathrm{a}}$ & Symptoms \\
\hline T3 & Florida & Lime & Decline/SP \\
T68 & Australia & Mandarin & Decline/SP \\
T4 & Florida & Citron & Mild $^{\mathrm{d}}$ \\
T30 & Florida & Orange & Mild $^{\mathrm{a}}$ \\
T49-1 & Florida & Orange & Mild \\
T55-1 & Florida & Orange & Mild \\
T56-1 & Florida & Orange & Mild \\
T36 & Florida & Orange & Decline \\
T64-1 & Florida & Grapefruit & Decline \\
T66-1 & Florida & Grapefruit & Decline \\
\hline
\end{tabular}

a Original source variety of the isolate.

b SP refers to stem-pitting in either grapefruit or orange.

c T68 was isolated from propagations of 'Ellendale' mandarin budwood imported from Australia without authorization.

d No significant symptoms on standard indicator hosts.

e Isolates with -1 designation were aphid-transmitted from the original field source. 
presented. The CTV genome structure is presented in Figure 1, with individual open reading frames (ORFs) indicated by number.

The T30 sequences that represent the $3^{\prime}$ and $5^{\prime}$ NTRs and eight of nine ORFs thought to be expressed from $3^{\prime}$ coterminal subgenomic RNAs are represented by clones R6, A9, R2, R3, R31, B10, R12, B18r, R14, and T6. The sequence samples from clones T3041, R19, R15, R27, T308, R38, R8, and R36 represent portions of the CTV genome thought to be expressed by the translation of the genomic RNA to produce a $>350-\mathrm{kDa}$ polyprotein.

The sequence identities obtained by paired comparisons of sequence from the $3^{\prime}$ NTR of T30 to those of VT and T36 were both 90\% (Table 2, clone R6). The T30 clones A9 through R31 represent sequence from ORFs 11, 10, 9, and 8, respectively, and the difference in sequence identity obtained from paired comparisons of T36 and VT to T30 did not exceed 4\% (Table 2). For the T30 sequences represented by clones B10 to R14, the sequence identity is higher overall between T30 and T36 $(90,92,88$, and 92\%, respectively) than between T30 and VT $(82,86,84$, and $82 \%$, respectively), although differences between paired comparisons at a given position did not exceed $10 \%$. Overall, there is an equivalent level of sequence identity between T30 and both T36 and VT in the 3' $8.4 \mathrm{~kb}$ of the genome.

The sequences derived from the $5^{\prime}$ proximal $10.9 \mathrm{~kb}$ of the T30 genome showed a contrasting situation. The sequence identities obtained from comparison of T30 clones T3041, R19, and R15 to VT were higher $(87,89$, and $93 \%$, respectively) than those obtained from comparisons to $\mathrm{T} 36$ ( 80,81 , and $88 \%$, respectively). A comparison of the sequences of T30 clones R27 through T6 to the T36 sequence showed a marked decline in sequence identity

TABLE 2. Nucleotide sequence analysis of cDNA clones of the Florida citrus tristeza virus (CTV) isolate T30 compared with the analogous regions of the genomes of the Florida CTV isolate T36 and the Israeli isolate VT

\begin{tabular}{lcccccc}
\hline Clone & $\begin{array}{c}\text { Size } \\
\text { (nt) }\end{array}$ & $\begin{array}{c}\text { T36 } \\
\text { position }^{\mathrm{a}}\end{array}$ & $\begin{array}{c}\text { T36 } \\
\text { identity }(\%)\end{array}$ & $\begin{array}{c}\text { VT } \\
\text { position }\end{array}$ & $\begin{array}{c}\text { VT } \\
\text { identity }(\%)\end{array}$ & ORF \\
\hline R6 & 142 & 19,152 & 90 & 19,087 & 90 & NTR $^{\mathrm{b}}$ \\
A9 & 172 & 18,401 & 84 & 18,332 & 87 & 11 \\
R2 & 122 & 18,198 & 74 & 18,029 & 77 & 10 \\
R3 & 143 & 17,889 & 90 & 17,820 & 94 & 10 \\
R31 & 157 & 17,186 & 83 & 17,115 & 80 & $8 / 9$ \\
B10 & 168 & 15,999 & 90 & 15,929 & 82 & $6 / 7$ \\
R12 & 183 & 14,679 & 92 & 14,607 & 86 & 5 \\
B18r & 134 & 13,951 & 88 & 13,879 & 84 & 5 \\
R14 & 131 & 12,543 & 92 & 12,472 & 82 & 4 \\
T3041 & 2,133 & 10,008 & 80 & 9,955 & 87 & $1 b^{c}$ \\
R19 & 144 & 9,808 & 81 & 9,755 & 89 & $1 \mathrm{~b}$ \\
R15 & 120 & 9,401 & 88 & 9,348 & 93 & $1 \mathrm{a}$ \\
R27 & 132 & 8,996 & 71 & 8,943 & 87 & $1 \mathrm{a}$ \\
T308 & 339 & 4,906 & 66 & 4,860 & 86 & $1 \mathrm{a}$ \\
R38 & 196 & 2,394 & 72 & 2,356 & 90 & $1 \mathrm{a}$ \\
R8 & 135 & 1,817 & 64 & 1,801 & 77 & $1 \mathrm{a}$ \\
R36 & 136 & 658 & 74 & 656 & 83 & $1 \mathrm{a}$ \\
T6 & 248 & 1 & 60 & 1 & 78 & NTR \\
\hline
\end{tabular}

a Position refers to the $5^{\prime}$-most nucleotide in the indicated T30 cDNA clone. b Refers to the 3' nontranslated sequences.

c Sequence covers part of open reading frames $1 \mathrm{~b}$, all of 2 and 3, and part of 4 .

${ }^{\mathrm{d}}$ Refers to the $5^{\prime}$ nontranslated sequences.
(71, 66, 72, 64, 74, and $60 \%$, respectively) toward the $5^{\prime}$ end of the genome. In contrast, the overall level of sequence identity between T30 and VT was much higher $(87,86,90,77,83$, and $78 \%$, respectively), and there was not the large decrease in sequence identity seen with isolate T36.

Sampling of T3 sequences. CTV isolate T3 is a Florida isolate that causes a decline disease similar to T36 (Table 1). Three T3-derived cDNA clones were selected based upon their strong signals and estimated genomic positions when hybridized to T3 dsRNA (data not shown). Table 3 lists the sizes in nucleotides of these three T3 clones, their genomic positions, and calculated nucleotide sequence identities with the positionally analogous sequences of the isolates T36 and VT. The sequence of the clones from the 3' proximal regions, 221 and T3/4, had a high level of sequence identity (>90\%) with both T36 and VT, whereas the level of sequence identity of the clone from the $5^{\prime}$ region, T3MT, was much higher when compared with VT (86\%) than with T36 (65\%). Although the number of $\mathrm{T} 3$ clones we compared is smaller than the number for isolate T30, the pattern of change in sequence identity moving from the $3^{\prime}$ to the $5^{\prime}$ end of the genome is similar for both T3 and T30 when each is compared individually with VT or T36.

Northern blot hybridization analysis of the $5^{\prime}$ region of the CTV genome. To expedite the sampling of a larger number of CTV isolates, Northern blot hybridization analysis was used to estimate the relatedness of 11 Florida isolates (Fig. 2A to C). In all cases, results presented are typical of those obtained with the indicated combination of probes and dsRNAs. The hybridization probes were the T36-derived clone k17 (nucleotides 4,871 to 5,279) (11), the positionally analogous T3-derived clone T3MT (T36 nucleotides 4,906 to 5,245) (Table 3), and the T30-derived clone T308 (T36 nucleotides 4,906 to 5,245 ) (Table 2). For the sake of convenience, we refer to these probes as k17 probes. Each lane in Figure 2A to C contains an equivalent amount of dsRNA of the indicated isolate, as determined from ethidium bromide-stained agarose gels.

The T36 k17 clone hybridized only to the dsRNA from T36, T64-1, and T66-1 (Fig. 2A). No hybridization signal was detected from any of the other isolates. The T3 k17 clone resulted in the strongest signals from the isolates T3 and T68, indicating a high level of sequence similarity between these isolates (Fig. 2B). Weaker and variable signals were obtained from the dsRNAs of the other isolates. The dsRNAs from T30-1, T49-1, and T55-1 produced signals equivalent to one another and stronger than those obtained for dsRNAs of T4, T30, and T56-1. Although the dsRNA of isolate T64-1 produced a faint signal with the $\mathrm{T} 3 \mathrm{k} 17$ probe, there was no signal from the dsRNAs of either T36 or T66-1.

TABLE 3. Nucleotide sequence identity of cDNA clones of the Florida citrus tristeza virus (CTV) isolate T3 compared with the analogous regions of the genomes of the Florida CTV isolate T36 and the Israeli CTV isolate VT

\begin{tabular}{lcccccc}
\hline Clone & $\begin{array}{c}\text { Size } \\
(\mathrm{nt})\end{array}$ & $\begin{array}{c}\text { T36 } \\
\text { position }^{\mathrm{a}}\end{array}$ & $\begin{array}{c}\text { T36 } \\
\text { identity }(\%)\end{array}$ & $\begin{array}{c}\text { VT } \\
\text { position }\end{array}$ & $\begin{array}{c}\text { VT } \\
\text { identity }(\%)\end{array}$ & ORF \\
\hline 221 & 155 & 18,597 & 92 & 18,528 & 93 & 11 \\
T3/4 & 174 & 17,716 & 92 & 17,695 & 95 & $9 / 10$ \\
T3MT & 339 & 4,906 & 65 & 4,860 & 86 & $1 \mathrm{a}$ \\
\hline
\end{tabular}

a Position refers to the $5^{\prime}$-most nucleotide in the indicated T3 cDNA clone.

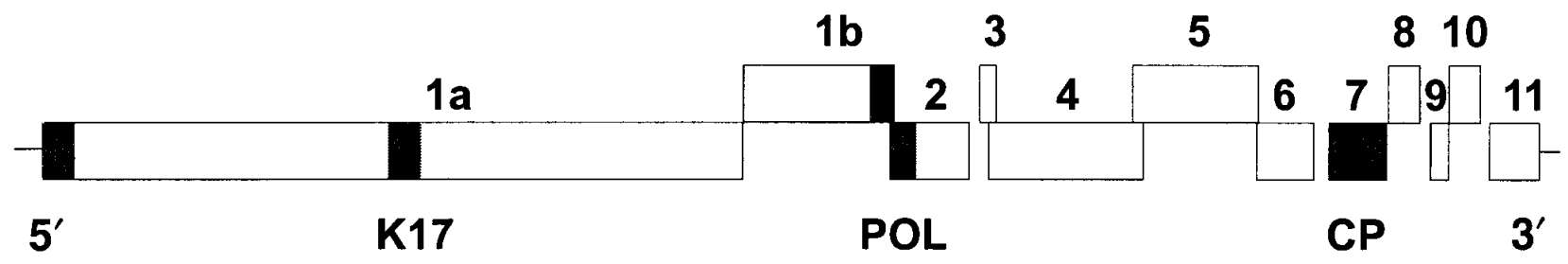

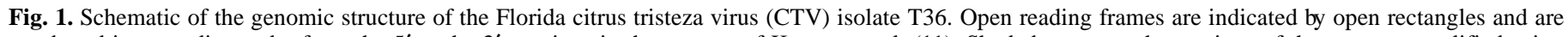

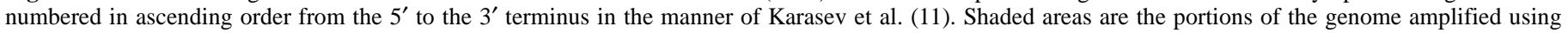
polymerase chain reaction and the amplified marker is indicated underneath. 
The T30 k17 probe generated no hybridization signal from the dsRNAs of isolates T36, T64-1, or T66-1 (Fig. 2C). Weak signals were obtained from the dsRNAs of isolates T3, T55-1, and T68, whereas much stronger signals were obtained from the dsRNAs of T4, T30, T30-1, T49-1, and T56-1. A difference in signals was observed between the dsRNAs of T30 and its aphid-transmitted subclone T30-1. The T30 k17 probe produced a much stronger signal from T30 dsRNA than did the T3 $\mathrm{k} 17$ probe (Fig. $2 \mathrm{~B}$ and C), whereas the two probes produced nearly equivalent signals with T30-1 dsRNA. Unexpectedly, the T3 $\mathrm{k} 17$ probe produced a stronger signal with the dsRNA of T55-1 than did the T30 k17 probe. The T30 k17 probe was expected to produce equivalent signals from isolates T30 and T55-1, which have similar biological properties.

Northern blot hybridization analysis of the $3^{\prime}$ region of the CTV genome. The sequence data in Tables 2 and 3 indicated that the CTV isolates T3, T30, T36, and VT shared a high level of nucleotide sequence identity in the $3^{\prime}$ portion of the genome. Figure $3 \mathrm{~A}$ to $\mathrm{C}$ depicts hybridization results using probes derived from the entirety of ORF 11 from the isolates T36, T3, and T30, respectively. For the individual blots, the amount of dsRNA loaded in each lane was equivalent for all isolates, as determined from ethidium bromide-stained agarose gels. The order of isolate-specific
dsRNAs is indicated at the top of each figure, and the isolates are the same as those depicted in Figure 2A to C.

Regardless of the source isolate for the probe, hybridization occurred with all of the isolates tested, demonstrating the overall sequence conservation of the $3^{\prime}$ portion of the CTV genome. The genomic, nine subgenomic, and numerous RNAs (presumed to be DRNAs) containing the ORF 11 sequence were detected in the dsRNA of the different isolates. The arrow on the left side of Figure $3 \mathrm{~A}$ to $\mathrm{C}$ indicates the subgenomic RNA for ORF 11 as identified from the profile of T36 subgenomic RNAs (10). The signal strength associated with the ORF 11 subgenomic RNA is dependent upon both sequence similarity to the probe as well as the amount present in the dsRNA preparation. The T36 ORF 11 probe produced a signal for all of the isolates assayed. The signals from the genomic RNAs of isolates T36 and T64-1 were strongest (Fig. 3A), whereas isolates T3, T66-1, and T68 showed nearly equivalent signal strengths when compared with one another, but had lesser signal intensities than T36 and T64-1. The isolates T4, T30, T30-1, T49-1, T55-1, and T56-1 had hybridization signals comparable to one another, but lower than signals from the other isolates. The T3 ORF 11 probe generated the strongest signals from the genomic dsRNAs for isolates T3 and T68 and much weaker signals for all

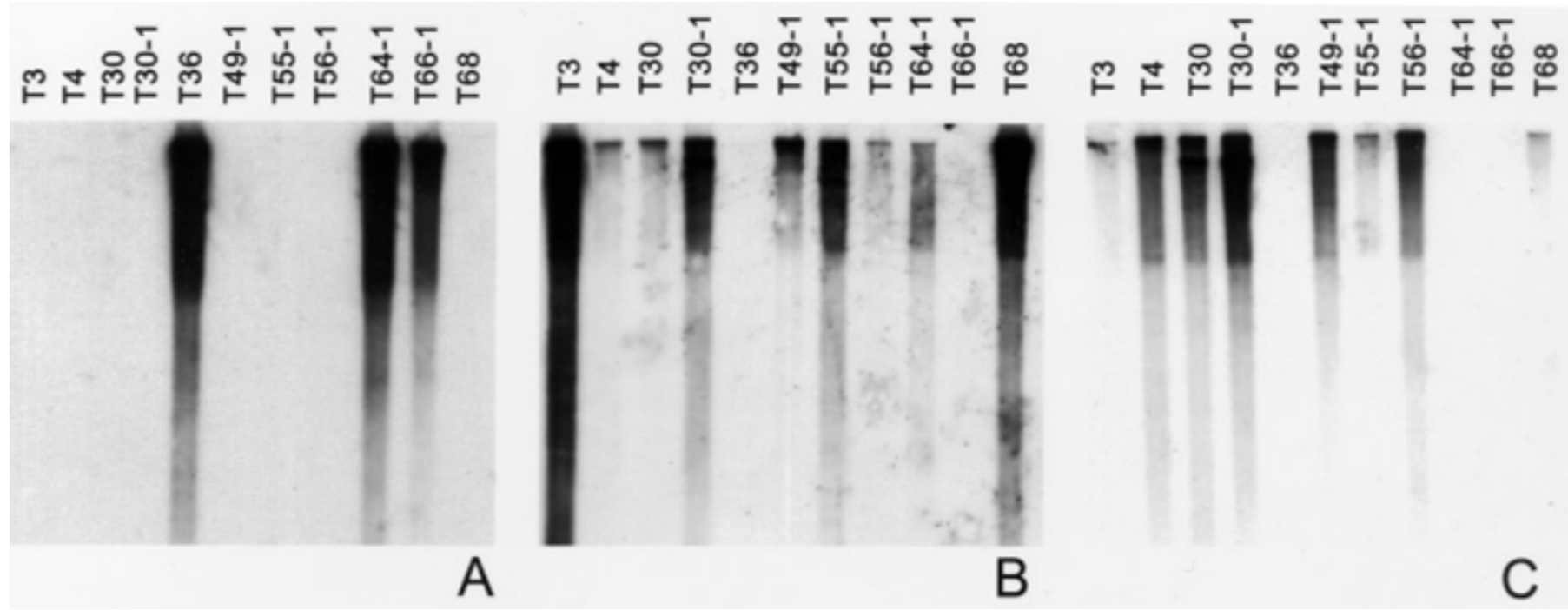

Fig. 2. Northern blot hybridization analysis of double-stranded RNAs (dsRNAs) of Florida citrus tristeza virus isolates. Source isolates are indicated at the top of each lane. Equivalent amounts of dsRNA were loaded into each lane. Blots were hybridized with probes made from positionally analogous sequences from open reading frame 1a (Fig. 1) of isolates A, T36; B, T3; and C, T30.

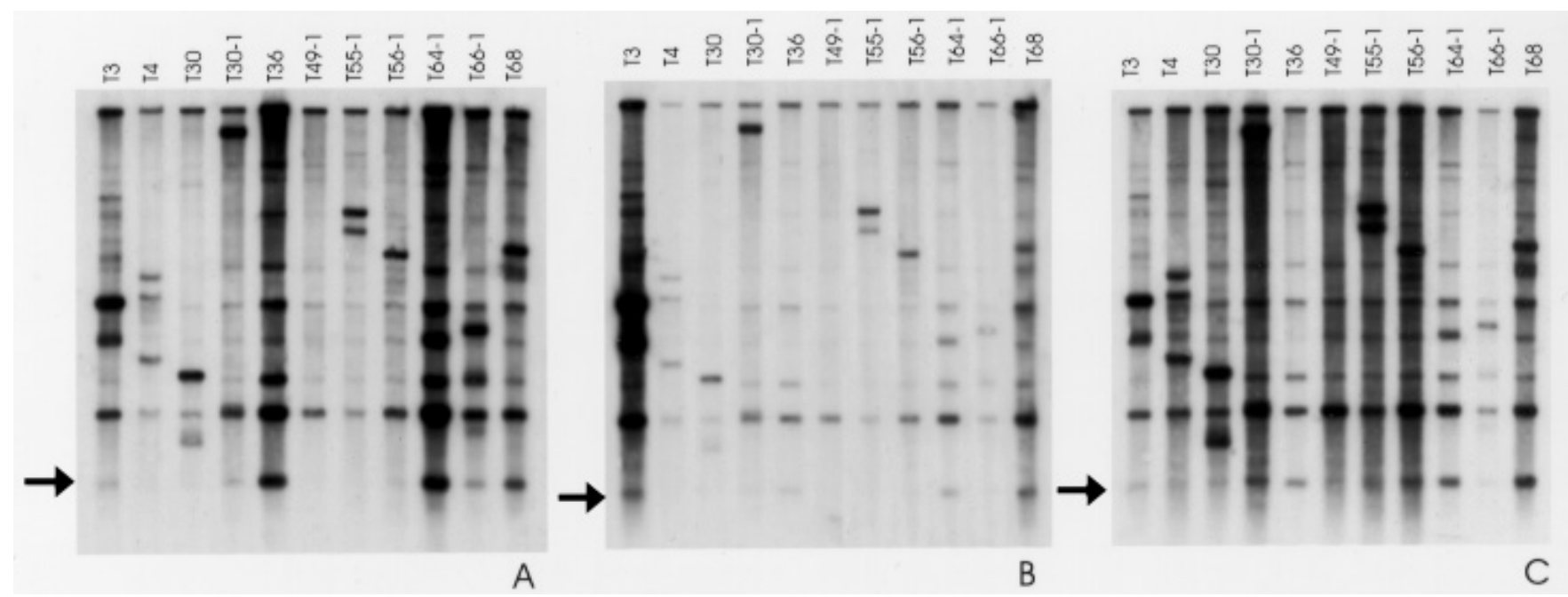

Fig. 3. Northern blot analysis of double-stranded RNAs (dsRNAs) of Florida citrus tristeza virus isolates. Source isolates are indicated at the top of each lane. Equivalent amounts of dsRNA were loaded into each lane. Hybridization was with polymerase chain reaction-derived probes from open reading frame (ORF) 11 of isolates A, T36; B, T3; and C, T30. Arrows indicate the subgenomic RNA for ORF 11. 
other isolates (Fig. 3B). The T30 ORF 11 probe generated a signal from all isolates tested, although isolates T36 and T66-1 showed the weakest signals from genomic RNA (Fig. 3C). Signals from genomic RNA were equivalent among the other isolates. Although there was variability in the resulting signal strengths, none of the probes discriminated between isolates to the same extent as the $5^{\prime}$ end probes.

Analysis of Florida CTV isolates using sequence-specific primer pairs. The cloned sequences of isolates T36, T30, and T3 presented in Tables 1 and 2 were used to design primer pairs for characterization of CTV using PCR. Table 4 shows the names and sequences of the primer pairs and the names of the amplified markers. The approximate genomic positions of the amplified markers are designated by the shading in Figure 1. CTV encodes two functional capsid protein genes $(5,24)$, and the primers $\mathrm{T} 36 \mathrm{cp}(+)$ and T36cp(-) were made from the nucleotide sequence of the highly conserved major capsid protein gene of the T36 isolate (Fig. 1, ORF 7).

Figure 4A shows that the T36 capsid protein primers amplified a product of the appropriate size from cDNA specific for 10 Florida isolates. The T36POL, T36K17, and T36-5' markers were amplified only from isolates T36, T64-1, and T66-1 (Fig. 4B to D, respectively). The T30POL and T30-5' markers were amplified only from isolates T30, T30-1, T49-1, T55-1, and T56-1 (Fig. 4E and F, respectively). Figure $4 \mathrm{G}$ shows that the T3K17 marker was amplified only from isolates T3 and T68. Overall, the identification of similar isolates by PCR agrees with the results obtained by Northern blot hybridization.

\section{DISCUSSION}

CTV is found in most of the major citrus-producing regions of the world and is responsible for several destructive disease syndromes. An assessment of biological characteristics suggested that CTV might not be a single virus, but a complex of similar viruses (19). However, the lack of serological discrimination between CTV isolates collected from regions that should have had limited exchange of viral germ plasm seemed to contradict this supposition. The capsid protein gene sequences from varied isolates were shown to be highly conserved $(8,16,22)$, potentially explaining the lack of serological discrimination. However, this picture of limited divergence between isolates was clouded by the asymmetric distribution of nucleotide sequence identity observed upon comparison of the complete VT and T36 genomic sequences (18). The

TABLE 4. Citrus tristeza virus (CTV) genotype-specific oligonucleotide primers used in polymerase chain reaction (PCR) analysis of CTV

\begin{tabular}{|c|c|c|}
\hline Primers $^{\mathrm{a}}$ & $\begin{array}{l}\text { Marker } \\
\text { amplified }\end{array}$ & Primer sequence $\left(5^{\prime} \rightarrow 3^{\prime}\right)$ \\
\hline $\begin{array}{l}\text { T36сp }(+) \\
\text { T36cp }(-)\end{array}$ & $\mathrm{CP}$ & $\begin{array}{l}\text { ATGGACGACGAAACAAAGAAATTG } \\
\text { CGTACTATGCATCAACGTGTGTTGAATTTCCCA }\end{array}$ \\
\hline $\begin{array}{l}\text { T36k17(+) } \\
\text { T36k17(-) }\end{array}$ & T36K17 & $\begin{array}{l}\text { GTTTTCTCGTTTGAAGCGGAAA } \\
\text { CAACACATCAAAAATAGCTAGT }\end{array}$ \\
\hline $\begin{array}{l}\text { T36pol(+) } \\
\text { T36pol(-) }\end{array}$ & T36POL & $\begin{array}{l}\text { TGACGCTAACGACGATAACG } \\
\text { ACCCTCGGCTTGTTTTCTTATG }\end{array}$ \\
\hline $\begin{array}{l}\mathrm{T} 36-5^{\prime}(+) \\
\mathrm{T} 36-5^{\prime}(-)\end{array}$ & $\mathrm{T} 36-5^{\prime}$ & $\begin{array}{l}\text { AATTTCACAAATTCAACCTG } \\
\text { CTTTGCCTGACGGAGGGACC }\end{array}$ \\
\hline $\begin{array}{l}\text { T30pol(+) } \\
\text { T30pol(-) }\end{array}$ & T30POL & $\begin{array}{l}\text { GATGCTAGCGATGGTCAAAT } \\
\text { CTCAGCTCGCTTTCTCGCAT }\end{array}$ \\
\hline $\begin{array}{l}\mathrm{T} 30-5^{\prime}(+) \\
\mathrm{T} 30-5^{\prime}(-)\end{array}$ & $\mathrm{T} 30-5^{\prime}$ & $\begin{array}{l}\text { CGATTCAAATTCACCCGTATC } \\
\text { TAGTTTCGCAACACGCCTGCG }\end{array}$ \\
\hline $\begin{array}{l}\text { T3k17(+) } \\
\text { T3k17(-) }\end{array}$ & T3K17 & $\begin{array}{l}\text { GTTATCACGCCTAAAGTTTGGT } \\
\text { CATGACATCGAAGATAGCCGAA }\end{array}$ \\
\hline
\end{tabular}

a Primers specific for each marker are listed in pairs.

${ }^{\mathrm{b}}$ Underlined nucleotides are non-CTV sequence.

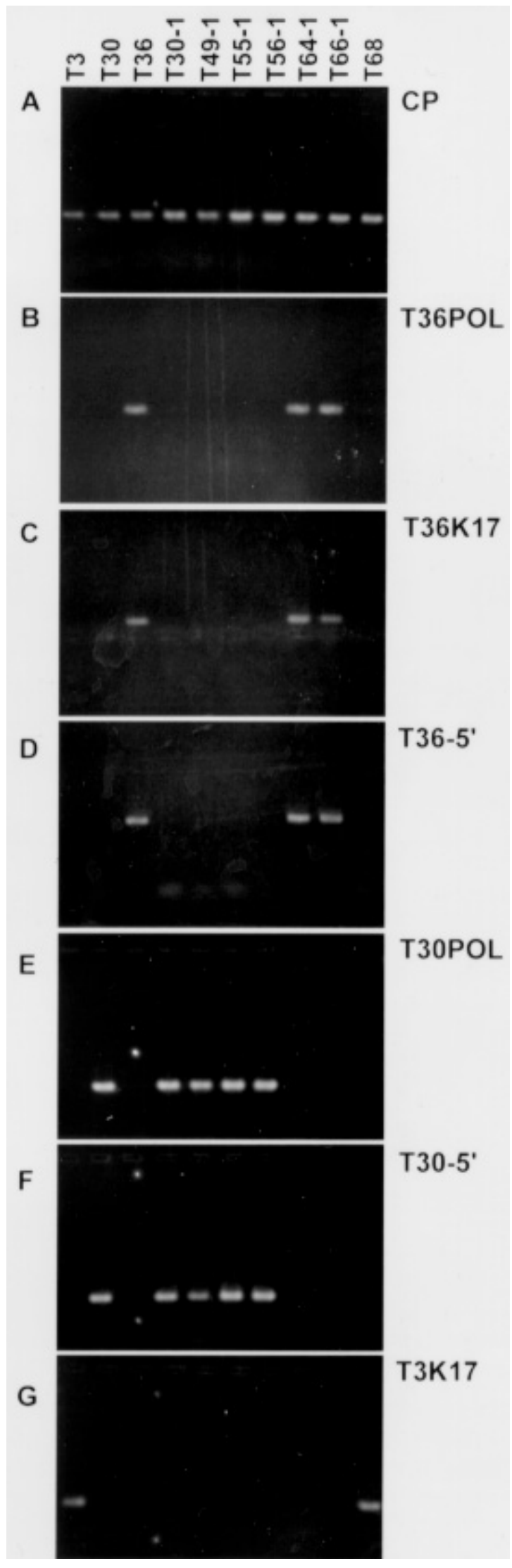

Fig. 4. Polymerase chain reaction products obtained from Florida citrus tristeza virus isolates using sequence-specific primers. The specific markers amplified by the primer pairs listed in Table 4 are designated to the right of the figure. Target isolates are indicated at the top of each lane, and the same lanes are aligned in each successive panel. 
overall constant level of nucleotide sequence identity in the $3^{\prime} 8 \mathrm{~kb}$ was in sharp contrast to the decline in identity seen within the $5^{\prime}$ $11 \mathrm{~kb}$. This unexpected characteristic provided impetus to examine other CTV isolates to determine whether this unusual pattern of divergence was a common characteristic of CTV.

Our analysis of cloned sequences of Florida isolates T3 and T30 showed that both genomes had a consistently high degree of nucleotide sequence similarity throughout the genome when compared with isolate VT. The analysis indicated also that the T3 and T30 genomes were diverged from T36 in the $5^{\prime} 11 \mathrm{~kb}$ in a manner similar to that of VT, and this was corroborated by a lack of crosshybridization between T36 and either T3 or T30 sequences in the $5^{\prime}$ region. In contrast, hybridization probes prepared from the ORF 11 of Florida isolates T3, T30, and T36 hybridized to the entire panel of 11 Florida CTV isolates, supporting the sequence data that indicated that this and other ORFs in the $3^{\prime} 8 \mathrm{~kb}$ were conserved.

Using these data as a guide, we propose a rudimentary classification scheme for CTV. All CTV isolates form an overall complex of citrus-infecting closteroviruses. The isolates VT and T36 represent two separate lineages in the development of CTV and, therefore, are selected as the type isolates of the VT and T36 groups. The isolates T3 and T30 are placed in the VT group as suggested by their sequence similarities, and members of a group would be considered to be strains of a virus. We further propose that VT, T3, T30, and T36 represent specific CTV "genotypes" and that other isolates can be similarly characterized. For example, using the results from the hybridization analysis with the $\mathrm{k} 17$ probes and the analysis by PCR with sequence-specific primers, we suggest that (i) T68 has a T3 genotype; (ii) T64-1 and T66-1 have T36 genotypes; and (iii) isolates T4, T30-1, T49-1, T55-1, and T56-1 have T30 genotypes.

The size of the CTV genome makes total genome characterization of unknown isolates a formidable task. The strategy we used of sampling sequences throughout the CTV genome is similar to one used to create accurate vertebrate phylogenies using partial sequences of mitochondrial genomes (3), which are comparable in size to the CTV genome. A potentially useful modification of this sampling strategy was the use of PCR with sequence-specific primer pairs derived from multiple sites within the more diverged $5^{\prime}$ region of the T3, T30, and T36 genomes. This technique distinguished between the VT and T36 groups of CTV, as well as between members within the VT group. Other isolates could be characterized in this manner, creating for each isolate a profile composed of a set of molecular markers.

It seems clear, however, that isolates sharing a similar genotype, as evaluated by PCR, are not identical. Although the isolates T30, T30-1, T49-1, T55-1, and T56-1 had the same genotype based upon PCR assays, variable hybridization signals indicated that some differentiation has occurred since the introduction of this genotype into Florida citrus. Similarly, PCR analysis characterized isolates T64-1 and T66-1 as both having a T36 genotype, but hybridization analysis of dsRNA indicated that T64-1 also had sequence similarity to isolate $\mathrm{T} 3$, which was not evident with either T36 or T66-1. Isolate T30-1 was derived from isolate T30 by aphid transmission, yet hybridization analysis of dsRNA showed quite striking differences between them, even though PCR analysis of both produced the same results. It would be interesting to determine the degree of nucleotide sequence divergence that may have occurred between isolates with the same genotype but derived from different citrus regions. For example, isolate T3 was isolated from a lime tree from an unrecorded location in Florida in or prior to 1957 (9), whereas T68 was isolated more than 20 years later from 'Ellendale' mandarin budwood imported without authorization into Florida from Australia (S. M. Garnsey, unpublished data). Isolates T3 and T68, therefore, may represent separate introductions of the same CTV genotype into Florida.

The PCR analysis of Florida isolates T49-1, T55-1, and T56-1 indicated that these isolates have the same genotype as isolate
T30. Since they also have similar biological characteristics, they may be descended by horticultural propagation and spread by aphids from a single or limited number of introductions of this particular genotype of CTV into Florida. The same may possibly be true for T36, T64-1, and T66-1. A preliminary screening of samples by PCR from infected commercial citrus trees in Florida indicates that the T30 and T36 genotypes are common, whereas the T3 genotype has yet to be detected in current commercial plantings (M. E. Hilf and S. M. Garnsey, unpublished data).

López et al. (13) reported recently that the $3^{\prime}$ NTR and ORF 11 of five Spanish CTV isolates were highly conserved, but that extensive nucleotide sequence variability exists in the $5^{\prime}$-most 267 nucleotides of five CTV isolates. Based upon this variation in the 5 ' sequence, the authors created CTV groups I, II, and III from these sequence data (13). Although the authors analyzed a different set of isolates, their data suggest similar conclusions about CTV sequence divergence.

The emerging picture of CTV is one of a virus with a high level of genetic complexity, and we feel that the data we have presented and discussed in this paper may be useful in the development of meaningful methods to measure and understand this variability. A clearer understanding of the molecular relationships between CTV isolates would be valuable information useful in making decisions concerning citrus scion and rootstock selection and in the selection of isolates for cross-protection in commercial citrus. Data from these types of analyses hopefully will improve our understanding of how the CTV genome has evolved, as well as our understanding of the similarities and differences in the CTV populations present in citrus from around the world.

\section{ACKNOWLEDGMENTS}

Florida Agricultural Experiment Station Journal Series R-06794. This work was supported, in part, through the USDA-ARS Cooperative Agreement 58-6617-4-018, by grants from the U.S.-Israel Binational Agricultural and Development Fund, by the Florida Citrus Production Research Advisory Council, and by an endowment in honor of J. R. and A. S. Graves. M. R. Albiach-Marti was a recipient of a fellowship from the Ministerio de Educación y Ciencia, Programa de Formación de Doctores y Tecnologos, Spain.

\section{LITERATURE CITED}

1. Ashoulin, L., Mawassi, M., and Bar-Joseph, M. 1992. Procedure to amplify cDNA from viroid RNA templates using the polymerase chain reaction. Methods Mol. Biol. 3:83-89.

2. Broadbent, P., Brlansky, R. H., and Indsto, J. 1996. Biological characterization of Australian isolates of citrus tristeza virus and separation of subisolates by single aphid transmissions. Plant Dis. 80:329-333.

3. Cummings, M. P., Otto, S. P., and Wakely, J. 1995. Sampling properties of DNA sequence data in phylogenetic analysis. Mol. Biol. Evol. 12: 814-822.

4. Devereux, J., Haeberll, P., and Smithies, O. 1984. A comprehensive set of sequence analysis programs for the VAX. Nucleic Acids Res. 12:387-395.

5. Febres, V. J., Ashoulin, L., Mawassi, M., Frank, A., Bar-Joseph, M., Manjunath, K. L., Lee, R. F., and Niblett, C. L. 1996. The p27 protein is present at one end of citrus tristeza virus particles. Phytopathology 86: 1331-1335.

6. Garnsey, S. M., Civerolo, E. L., Gumpf, D. J., Yokomi, R. K., and Lee, R. F. 1991. Development of a worldwide collection of citrus tristeza virus isolates. Pages 113-120 in: Proc. Conf. Int. Organ. Citrus Virol., 11th. International Organization of Citrus Virologists, c/o Department of Plant Pathology, University of California, Riverside.

7. Garnsey, S. M., and Jackson, J. L. 1975. A destructive outbreak of tristeza in central Florida. Proc. Fla. State Hortic. Soc. 80:65-69.

8. Gillings, M., Broadbent, P., Indsto, J., and Lee, R. 1993. Characterization of isolates and strains of citrus tristeza closterovirus using restriction analysis of the coat protein gene amplified by the polymerase chain reaction. J. Virol. Methods 44:305-317.

9. Grant, T. J., and Higgins, R. P. 1957. Occurrence of mixtures of tristeza virus strains in citrus. Phytopathology 47:272-276.

10. Hilf, M. E., Karasev, A. V., Pappu, H. R., Gumpf, D. J., and Garnsey, S. M. 1995. Characterization of citrus tristeza virus subgenomic RNAs in 
infected tissue. Virology 208:576-582.

11. Karasev, A. V., Boyko, V. P., Gowda, S., Nikolaeva, O. V., Hilf, M. E., Koonin, E. V., Niblett, C. L., Cline, K., Gumpf, D. J., Lee, R. F., Garnsey, S. M., Lewandowski, D. J., and Dawson, W. O. 1995. Complete sequence of the citrus tristeza virus RNA genome. Virology 208:511-520.

12. Karasev, A. V., Nikolaeva, O. V., Koonin, E. V., Gumpf, D. J., and Garnsey, S. M. 1994. Screening of the closterovirus genome by degenerate primer-mediated polymerase chain reaction. J. Gen. Virol. 75:1415-1422.

13. López, C., Ayllón, M. A., Navas-Castillo, J., Guerri, J., Moreno, P., and Flores, R. 1998. Molecular variability of the $5^{\prime}$ - and $3^{\prime}$-terminal regions of citrus tristeza virus RNA. Phytopathology 88:685-691.

14. Maniatis, T., Fritsch, E. F., and Sambrook, J. 1982. Molecular Cloning: A Laboratory Manual. Cold Spring Harbor Laboratory, Cold Spring Harbor, NY.

15. Mawassi, M., Ashoulin, L., Hilf, M. E., Mitkiewska, E., Gafny, R., Karasev, A. V., Garnsey, S. M., Lee, R. F., Dawson, W. O., and BarJoseph, M. 1995. Multiple species of defective RNAs in plants infected with citrus tristeza virus. Virology 214:264-268.

16. Mawassi, M., Gafny, R., and Bar-Joseph, M. 1993. The nucleotide sequence of the coat protein gene of citrus tristeza virus: Comparison of biologically diverse isolates collected in Israel. Virus Genes 7:265-275.

17. Mawassi, M., Karasev, A. V., Mitkiewska, E., Gafny, R., Lee, R. F., Dawson, W. O., and Bar-Joseph, M. 1995. Defective RNA molecules associated with citrus tristeza virus. Virology 208:383-386.

18. Mawassi, M., Mietkiewska, E., Gofman, R., Yang, G., and Bar-Joseph, M. 1996. Unusual sequence relationships between two isolates of citrus tristeza virus. J. Gen. Virol. 77:2359-2364.

19. McClean, A. P. D. 1974. The Tristeza Virus Complex. Pages 59-66 in:
Proc. Conf. Int. Organ. Citrus Virol., 6th. University of California, Division of Agricultural Sciences, Riverside.

20. Moreno, P., Guerri, J., Ballester-Olmos, J. F., Fuertes-Polo, C., Albiach, R., and Martinez, M. 1993. Variations in pathogenicity and double-stranded RNA (dsRNA) patterns of citrus tristeza virus isolate induced by host passage. Pages 8-15 in: Proc. Conf. Int. Organ. Citrus Virol., 12th. International Organization of Citrus Virologists, c/o Department of Plant Pathology, University of California, Riverside.

21. Moreno, P., Guerri, J., and Muñoz, N. 1990. Identification of Spanish strains of citrus tristeza virus by analysis of double-stranded RNA. Phytopathology 80:477-482.

22. Pappu, H., Pappu, S., Niblett, C., and Civerolo, E. 1993. Comparative sequence analysis of the coat protein of biologically distinct citrus tristeza closterovirus isolates. Virus Genes 7:255-264.

23. Schuler, G. D., Altschul, S. F., and Lipman, D. J. 1991. A workbench for multiple alignment construction analysis. Proteins Struct. Funct. Genet. 9:180-190.

24. Sekiya, M. E., Lawrence, S. D., McCaffery, M., and Cline, K. 1991. Molecular cloning and nucleotide sequencing of the coat protein gene of citrus tristeza virus. J. Gen. Virol. 72:1013-1020.

25. Valverde, R. A., Nameth, S. T., and Jordan, R. L. 1990. Analysis of double-stranded RNA for plant virus diagnosis. Plant Dis. 74:255-258.

26. Yokomi, R. K., Garnsey, S. M. G., Permar, T. M., Lee, R. F., and Youtsey, C. O. 1991. Natural spread of severe citrus tristeza isolates in citrus preinfected with mild CTV isolates. Pages 86-92 in: Proc. Conf. Int. Organ. Citrus Virol., 11th. International Organization of Citrus Virologists, c/o Department of Plant Pathology, University of California, Riverside. 